\title{
IDENTIFICATION OF HIGH YIELD CLONES OF ABACA (MUSA TEXTILIS NEE) MUTANTS BASED ON MORPHOLOGICAL CHARACTERS
}

\author{
Purwati Rully Dyah*, Parnidi, Setyo-Budi Untung, Herwati Anik \\ Indonesian Sweetener and Fibre Crops Research Institute, Malang, Indonesia \\ *E-mail: rdpurwati@gmail.com
}

\begin{abstract}
Abaca (Musa textilis Nee) is one of fiber crops which produced fiber as raw materials of rope ships and high quality papers. Improvement of abaca new varieties needs sufficient genetic materials so the expected new varieties can be produced. Abaca is normally multiplied clonally, so abaca has narrow genetic diversity. To increase genetic diversity of abaca, the chemical mutation by ethylmethane sulphonate (EMS) was done. ISFCRI has completed chemical mutation on abaca accessions Sangihe I and Tangongon. Twenty six abaca mutants were planted in Cobanrondo experimental station in Malang, at 1,450 m above sea level. Each mutant genotype was planted in a clump, with three meter spacing between clumps. Based on morphological character studies, chemical mutation of abaca Sangihe I and Tangongon clones using $0.6 \%$ EMS increased the variability of stalk number character (CV 91\%). All quantitative characters observed have positive and significant correlation to weight of dry leaves sheats as indicator of fibre production character. Meanwhile, the qualitative characters diversity was not raised by chemical mutation. Eight mutant clones indicated superiority and potential to be improved as high yield clones of abaca i.e. Clone 3: Sh 1.1.1-2, Clone 6: Sh 4.1.2-2, Clone 11: FK Sh 1.1-3-6, Clone 15: Tg 3.1-2, Clone 17: Tg 59.2-7, Clone 26: Tg 70.2.3-7, Clone 13: FK Sh 1.1.3-10, and Clone 18: Tg 59.2-8.
\end{abstract}

\section{KEY WORDS}

Diversity, germplasm, abaca, mutant, ethylmethane sulphonate.

Abaca (Musa textilis Nee) is one of the fibre crops originated from Philippines and known as Manila hemp (Zapico et al., 2010; Batalon et al., 2014). Abaca fibre is mostly used as raw material of cloth, footwear, pulp, and paper industries, and recently used as fibre composite for the automotive industry (Dizon et al., 2012). Pulp and paper produced from abaca fiber has advantages including tear resistant, difficult to be emulated and high quality papers (Santoso et al., 2016).

In Indonesia, improvement of abaca high yielding varieties using conventional breeding is difficult due to the narrow genetic variability and the sterile seed obtained from abaca hybridization. Setyo-Budi et al. (2001) reported that germplasm collection of abaca in Indonesian Sweetener and Fibre Crops Research Institute (ISFCRI) was only 47 accessions. This circumstance affects the difficulties of breeders to choose the parents for hybridization.

An alternative solution in increasing genetic diversity is creating somaclonal variation by tissue culture techniques. This method has been widely applied to improve genetic variability of horticultural crops (Khrisna et al., 2016). Combination of somaclonal variation induction and gene mutation will produce more variants that may have superiority in some characters. Plant mutation breeding can be conducted chemically and physically using irradiation.

Chemical mutagent widely used in plant mutation are cholchicine for chromosome doubling; nitrous acid $\left(\mathrm{HNO}_{2}\right)$, hydroxyl-amine $\left(\mathrm{NH}_{2} \mathrm{OH}\right)$, methyl methane sulphonate (MMS) and ethyl methane sulphonate (EMS) for induction of random mutation in DNA bases (Russell, 1992). EMS is alkyl compound and has competency to induce mutation on various plants. EMS has been extensively used in increasing genetic variability of some plants: potato (Zia et al., 2018), Cucumber (Wang et al., 2014), rape-seed (Yadav et al., 2016), rice (Wattoo et al., 2013), carnation (Roychowdhury \& Tah, 2011), Petunia (Berenschot et al., 2008), and Abaca (Purwati et al., 2008). Meanwhile, Dizon et al. (2012) used Cobalt 60 
$\left({ }^{60} \mathrm{Co}\right)$ to induce abaca resistant lines to two strains of virus. The aim of this research is to identify the abaca mutants that are potential improved as high yield clones based on morphological characters.

\section{MATERIALS AND METHODS OF RESEARCH}

Genetic materials used in this experimant consisted of 26 clones of abaca mutant resulted from chemical mutation using $0.6 \%$ EMS (Table 1.). The abaca mutants and two clones of abaca non-mutants (parents) i.e. Sangihe I and Tangongon were planted in 2008, in Cobanrondo experimental station, Malang, East Java. This station is located at $1,450 \mathrm{~m}$ above sea level; the annual rainfall is $1,721 \mathrm{~mm}$ per year or including the $E$ climate category (Ferguson). Each clone was planted in a clump of plants with three meters plant spacing between clumps.

The plants were maintained by weeding and fertilizer. The fertilizer consisted of organic and anorganic compound, and the application was twice a year i.e. at the beginning of rainy season (November) and beginning of dry season (May). The dosage of each application was $300 \mathrm{~kg} \mathrm{ha}^{-1}$ of Urea, $650 \mathrm{~kg} \mathrm{ha}^{-1}$ of Phonska, and 20 tones ha ${ }^{-1}$ of organic manure.

The observation was conducted at five years after planting in January - December 2014. The quantitative and qualitative morphological characters were observed on 12 months old of abaca plants. Quantitative characters consisted of stem height, stem girth, number of stalk per clump, leaf sheats number of harvested plants, weight of wet leaf sheats, weight of dry fibre, and fibre content. Meanwhile, qualitative characters were tapering along length of pseudoterm, stem color, intensity of antocyanin coloration on stem, growth habit, attitute of wings at base petiole, midrib on lower side color of leaf blade, and base shape of leaf blade. Observation of morphological characters was refered to UPOV of banana (UPOV, 2008). Data analysis of quantitative characters was conducted using average \pm standard deviation and correlation between each character from three plants each.

Table 1 - List of abaca mutant clones

\begin{tabular}{|c|c|c|c|}
\hline No. & Mutants derived from Clone: Sangihe I & No. & Mutants derived from Clone: Tangongon \\
\hline 1. & Clone 1: Sh 10.1-2 & 15. & Clone 15: $\operatorname{Tg} 3.1-2$ \\
\hline 2. & Clone 2: Sh 10.1-3 & 16. & Clone 16: $\operatorname{Tg} 59.2-5$ \\
\hline 3. & Clone 3: Sh 1.1.1-2 & 17. & Clone 17: $\operatorname{Tg} 59.2-7$ \\
\hline 4. & Clone 4: Sh 17.1.2-3 & 18. & Clone 18: $\operatorname{Tg} 59.2-8$ \\
\hline 5. & Clone 5: Sh 28.2.2-4 & 19. & Clone 19: $\operatorname{Tg} 70.2-9$ \\
\hline 6. & Clone 6: Sh 4.1.2-2 & 20. & Clone 20: AF Tg 70.3.1.1-2 \\
\hline 7. & Clone 7: Sh 42.2-1 & 21. & Clone 21: AF Tg 70.3.1.1-6 \\
\hline 8. & Clone 8: Sh 42.2-8 & 22. & Clone 22: AF Tg 3.2.1.1-1 \\
\hline 9. & Clone 9: FK Sh 10.1-2 & 23. & Clone 23: AF Tg 3.2.1.1-2 \\
\hline 10. & Clone 10: FK Sh 10.1-3 & 24. & Clone 24: AF Tg 3.2.1.1-3 \\
\hline 11. & Clone 11: FK Sh 1.1-3-6 & 25. & Clone 25: AF Tg 3.2.1.1-4 \\
\hline 12. & Clone 12: FK Sh 1.1-3-7 & 26. & Clone 26: $\operatorname{Tg} 70.2 .3-7$ \\
\hline 13. & Clone 13: FK Sh 1.1.3-10 & & \\
\hline 14. & Clone 14: FK Sh 4.1.1-4 & & \\
\hline
\end{tabular}

\section{RESULTS AND DISCUSSION}

Since morphological characters (phenotype) was performed an interaction between genetic and environment, these become important in identification of superiority plants. Morphological characters observed in this experiment consisted of quantitative characters i.e. stem height, stem girth, stalk number per clump, leaves sheats number per plant, weight of wet leaves sheats, weight of dry fibre, and fibre content. Meanwhile, qualitative characters consisted of tapering along length of pseudoterm, stem color, intensity of antocyanin coloration on stem, growth habit, attitute of wings at base petiole, midrib on lower side of leaf blade color, and shape of base of leaf blade. The average of quantitative characters, standard deviation, and coefficient variation (CV) are presented in Table 2. To identify correlation between each character, the quantitative characters were also analysed using 
correlation. Almost all characters have positive correlation and significant at $1 \%$ of t-test, except fibre content (Table 3).

Table 2 - Quantitative morphological characters of abaca mutant clones

\begin{tabular}{|c|c|c|c|c|c|}
\hline No & Quantitative Characters & Average & & STDV & $\mathrm{CV}(\%)$ \\
\hline 1. & Stem height $(\mathrm{cm})$ & 198.96 & \pm & 23.01 & 11.57 \\
\hline 2. & Stalk number & 9.93 & \pm & 9.03 & 91.00 \\
\hline 3. & Stem girth $(\mathrm{cm})$ & 41.90 & $\underline{ \pm}$ & 5.29 & 12.62 \\
\hline 4. & No. of leaves sheats/plant & 2.85 & \pm & 0.52 & 18.47 \\
\hline 5. & Weight of wet leaves sheats/plant $(\mathrm{g})$ & 2.66 & \pm & 0.97 & 36.65 \\
\hline 6. & Weight of dry fibre/plant (g) & 0.07 & \pm & 0.03 & 37.15 \\
\hline 7. & Fibre content $(\%)$ & 2.77 & $\underline{ \pm}$ & 0.43 & 15.60 \\
\hline
\end{tabular}

In this result, the variability of quantitative morphological characters was categorized into three groups. The low diversity (CV 0-25\%) was found in stem height, stem girth, number of leaves sheats per plant, and fibre content. Moderately low diversity (CV 25-50\%) was obtained on weight of wet leaves sheats and dry fibre characters. The high diversity $(75 \%-100 \%)$ was observed on stalk number per clump. Grouping characters was refered to Moedjiono and Mejaya (1994), they divided the coefficient of variation into four criteria i.e. low (0\%-25\%), moderately low (25\%-50\%), moderately high (50\%-75\%), and high (75\%$100 \%)$. Data in Table 2 showed that quantitative characters of abaca are in narrow genetic variability. Only stalk number character presented a high coefficient variation $(91 \%)$, indicated the high genetic variability of this character. The high number of new stalk has positive correlation in fibre production improvement of abaca, because more number of new stalk will provide more stalks to be harvested.

In this experiment, all quantitative characters have significancy and positive correlation to dry fibre weight per plant (Table. 3). Weight of dry fibre per plant is one of fibre production components. All quantitative morphological characters observed in this experiment are valuable characters in supporting new abaca high yield clones. These results similar to Heliyanto et al. (1999), they reported that stem height, stalk number, and weight of wet stem, had positive and significant correlation to fibre production. On the other hand, most quantitative characters observed in this research have negative correlation to fibre content. The fibre content was still low due to the harvesting time was too early, the plants were harvested on 12 months (normally 18 months). La-Vina (1993) also reported that dry fibre yield was not only influenced by stem height, stem girth, and all parameters of fibre quality, but significantly interacted with environments.

Table 3 - The correlation between each quantitative character of abaca mutants

\begin{tabular}{|l|l|l|l|l|l|l|l|}
\hline No. & Characters & SN & SG & NLS & WLS & DF & FC \\
\hline 1 & Stem height (SH) & 0.169 & $0.585^{* *}$ & $0.505^{* *}$ & $0.699^{* *}$ & $0.652^{* *}$ & -0.045 \\
\hline 2 & Stalk number (SN) & & 0.229 & $0.431^{*}$ & 0.372 & $0.482^{* *}$ & 0.117 \\
\hline 3 & Stem girth (SG) & & & $0.836^{* *}$ & $0.932^{* *}$ & $0.844^{* *}$ & -0.233 \\
\hline 4 & No. of leaves sheats (NLS) & & & & $0.900^{* *}$ & $0.772^{* *}$ & -0.310 \\
\hline 5 & Weight of wet leaves sheats (WLS) & & & & & $0.892^{* *}$ & -0.250 \\
\hline 6 & Weight of dry fibre (DF) & & & & & & 0.157 \\
\hline 7 & Fibre content (FC) & & & & & & \\
\hline
\end{tabular}

Notice: * Significant at 5\%; ** Significant at $1 \%$.

The superiority and speed of abaca growth is indicated by stem height. Twenty six mutant clones showed variation on growth condition in Cobanrondo experimental station (Table 4). Stem height of some mutants were higher than their parents i.e. Clone 3: Sh 1.1.12, Clone 6: Sh 4.1.2-2, Clone 11: FK Sh 1.1-3-6, Clone 15: Tg 3.1-2, Clone 17: Tg 59.2-7, Clone 26: $\mathrm{Tg}$ 70.2.3-7. The stalk number increased from 27 (non-mutant) to 35 for Sagihe I, and from 4 to 14 for Tangongon. The clone with the highest stalk number is Clone 13: FK Sh 1.1.3-10. The biggest stem girth was observed on Clone 18: Tg 59.2-8. These eight mutant clones indicated superiority and potential to be improved as high yield clones of abaca. 
Mutants derived from Tangongon mostly have better performance than their parent (nonmutant).

Table 4 - Quantitative morphological characters of individual abaca mutants and parents (non mutants)

\begin{tabular}{|c|c|c|c|c|c|c|c|c|}
\hline No & Clones & $\begin{array}{c}\text { Stem } \\
\text { height } \\
\ldots \mathrm{cm} . .\end{array}$ & $\begin{array}{c}\text { Stalk } \\
\text { number }\end{array}$ & $\begin{array}{l}\text { Stem girth } \\
\quad \ldots \mathrm{cm} . .\end{array}$ & $\begin{array}{l}\text { No. of } \\
\text { leaves } \\
\text { sheats }\end{array}$ & $\begin{array}{c}\text { Weight of } \\
\text { wet leaves } \\
\text { sheats } \\
\text {...g... }\end{array}$ & $\begin{array}{c}\text { Weight of } \\
\text { dry leaves } \\
\text { sheats } \\
\text {...g... }\end{array}$ & $\begin{array}{c}\text { Fibre } \\
\text { content } \\
\ldots \% \ldots\end{array}$ \\
\hline 1 & Sangihe I (parent) & 217.50 & 27.00 & 51.50 & 3.50 & 4.34 & 0.14 & 3.19 \\
\hline 2 & Clone 1:Sh 10.1-2 & 155.00 & 8.00 & 41.67 & 3.00 & 2.31 & 0.04 & 1.83 \\
\hline 3 & Clone 2: Sh 10.1-3 & 203.33 & 7.00 & 39.33 & 2.89 & 2.49 & 0.08 & 3.24 \\
\hline 4 & Clone 3: Sh 1.1.1-2 & 218.50 & 16.00 & 43.50 & 3.33 & 3.95 & 0.09 & 2.22 \\
\hline 5 & Clone 4: Sh 17.1.2-3 & 175.00 & 2.00 & 42.00 & 3.00 & 2.27 & 0.06 & 2.73 \\
\hline 6 & Clone 5: Sh 28.2.2-4 & 200.00 & 2.00 & 44.33 & 3.33 & 2.91 & 0.08 & 2.69 \\
\hline 7 & Clone 6: Sh 4.1.2-2 & 241.00 & 25.00 & 48.50 & 3.33 & 4.01 & 0.12 & 3.00 \\
\hline 8 & Clone 7: Sh 42.2-1 & 177.50 & 26.00 & 42.50 & 3.17 & 2.86 & 0.07 & 2.44 \\
\hline 9 & Clone 8: Sh 42.2-8 & 214.00 & 11.00 & 46.50 & 3.33 & 3.82 & 0.09 & 2.48 \\
\hline 10 & Clone 9: FK Sh 10.1-2 & 186.00 & 2.00 & 39.00 & 2.67 & 2.04 & 0.06 & 3.12 \\
\hline 11 & Clone 10: FK Sh 10.1-3 & 198.00 & 8.00 & 39.00 & 2.33 & 2.30 & 0.07 & 3.38 \\
\hline 12 & Clone 11: FK Sh 1.1-3-6 & 221.33 & 21.00 & 40.33 & 2.89 & 2.81 & 0.09 & 3.40 \\
\hline 13 & Clone 12: FK Sh 1.1-3-7 & 173.00 & 6.00 & 39.00 & 2.56 & 1.92 & 0.06 & 3.18 \\
\hline 14 & Clone 13: FK Sh 1.1.3-10 & 185.33 & 35.00 & 40.67 & 3.33 & 2.65 & 0.08 & 3.11 \\
\hline 15 & Clone 14: FK Sh 4.1.1-4 & 192.33 & 2.00 & 36.67 & 2.67 & 2.13 & 0.06 & 2.77 \\
\hline 16 & Tangongon (parent) & 218.50 & 4.00 & 40.83 & 2.67 & 2.51 & 0.06 & 2.57 \\
\hline 17 & Clone 15: Tg 3.1-2 & 221.00 & 7.00 & 47.33 & 3.22 & 3.16 & 0.09 & 2.82 \\
\hline 18 & Clone 16: Tg 59.2-5 & 183.67 & 10.00 & 38.00 & 2.44 & 1.87 & 0.05 & 3.00 \\
\hline 19 & Clone 17: Tg 59.2-7 & 236.67 & 14.00 & 43.67 & 3.56 & 3.54 & 0.07 & 2.04 \\
\hline 20 & Clone 18: Tg 59.2-8 & 216.67 & 6.00 & 53.33 & 3.78 & 4.59 & 0.10 & 2.23 \\
\hline 21 & Clone 19: Tg 70.2-9 & 179.50 & 10.00 & 35.75 & 2.25 & 1.41 & 0.04 & 2.42 \\
\hline 22 & Clone 20: AF Tg 70.3.1.1-2 & 166.33 & 9.00 & 42.67 & 2.56 & 2.22 & 0.06 & 2.67 \\
\hline 23 & Clone 21: AF Tg 70.3.1.1-6 & 182.50 & 4.00 & 37.00 & 2.33 & 1.69 & 0.05 & 3.49 \\
\hline 24 & Clone 22: AF Tg 3.2.1.1-1 & 211.33 & 5.00 & 38.67 & 2.11 & 1.84 & 0.05 & 2.72 \\
\hline 25 & Clone 23: AF Tg 3.2.1.1-2 & 168.00 & 5.00 & 33.67 & 1.89 & 1.32 & 0.04 & 2.70 \\
\hline 26 & Clone 24: AF Tg 3.2.1.1-3 & 215.00 & 1.00 & 49.67 & 2.89 & 3.50 & 0.10 & 3.01 \\
\hline 27 & Clone 25: AF Tg 3.2.1.1-4 & 185.00 & 4.00 & 31.00 & 1.70 & 0.56 & 0.01 & 2.87 \\
\hline 28 & Clone 26: Tg 70.2.3-7 & 229.00 & 1.00 & 47.00 & 3.00 & 3.37 & 0.07 & 2.16 \\
\hline
\end{tabular}

Table 5 - Qualitative morphological characters of abaca mutants

\begin{tabular}{|l|l|l|}
\hline Qualitative characters & Persentage (\%) \\
\hline Pseudoterm: tapering along length & Absen or weak & 53.57 \\
\cline { 2 - 3 } & Medium & 46.43 \\
\cline { 2 - 3 } & Strong & 0.00 \\
\hline \multirow{5}{*}{ Stem color } & Weak & 60.71 \\
\cline { 2 - 3 } & Medium & 39.29 \\
\cline { 2 - 3 } & Strong & 0.00 \\
\cline { 2 - 3 } & Verry strong & 0.00 \\
\hline \multirow{5}{*}{ Gntensity of antocyanin coloration } & Weak & 0.00 \\
\cline { 2 - 3 } & Medium & 0.00 \\
\cline { 2 - 3 } & Strong & 96.43 \\
\cline { 2 - 3 } & Verry strong & 3.57 \\
\hline \multirow{5}{*}{ Petiole: attitute of wings at base } & Upright & 53.57 \\
\cline { 2 - 3 } & Spreading & 46.43 \\
\cline { 2 - 3 } & Drooping & 0.00 \\
\hline \multirow{5}{*}{ Leaf blade: shape of base } & Curved outwards & 100.00 \\
\cline { 2 - 3 } & Straight & 0.00 \\
\cline { 2 - 3 } & Slightly curved inwards & 0.00 \\
\cline { 2 - 3 } & Moderatly curved inward & 0.00 \\
\cline { 2 - 3 } & Overlapping & 0.00 \\
\hline \multirow{5}{*}{ Leaf blade: midrib color on lower side } & Yellow & 0.00 \\
\cline { 2 - 3 } & Green & 100.00 \\
\cline { 2 - 3 } & Pink & 0.00 \\
\cline { 2 - 3 } & Purple & 0.00 \\
\cline { 2 - 3 } & Black purple & 0.00 \\
\hline & Both sides rounded & 53.57 \\
\cline { 2 - 3 } & One side acute and one side rounded & 0.00 \\
\cline { 2 - 3 } & Both sides acute & 46.43 \\
\cline { 2 - 3 } & Both sides rounded with distance & \\
\hline
\end{tabular}


Some mutants showed worse growth condition than parent (non-mutant). Dwiatmini (2009) stated mutation induction may offer negative effect to plant genom due to gene damage. These conditions disturbed the growth of mutant plants and bring about abnormal or worse growth than their parent. Gichner (2003) pronounced that decreasing quantitative characters was affected by random mutation. Purwati et al. (2008) reported that EMS treatments created some abaca mutants with various negative and positive of qualitative and quantitative characters such as leaf shapes and abnormalities of plant growth.

Qualitative morphological characters of abaca mutants were categorized in low genetic diversity. The variation of tapering along length of pseudoterm, stem color, intensity of antocyanin coloration, growth habit, and base shape of leaf blade was not affected by chemical mutation, but mostly occurred due to the different genotype (Sangihe I and Tangongon). There is not diversity on attitute of wings at base petiole and midrib color on lower side of leaf blade characters (Table 5).

\section{CONCLUSION}

Chemical mutation of abaca Sangihe and Tangongon clones using $0.6 \%$ EMS increased in diversity of quantitative characters i.e. stalk number (CV 91\%). Meanwhile chemical mutation of abaca did not produce diversity of qualitative characters. All quantitative characters observed have positive and significant correlation to weight of dry fibre which is indicating fibre production. Eight mutant clones i.e. Clone 3: Sh 1.1.1-2, Clone 6: Sh 4.1.2-2, Clone 11: FK Sh 1.1-3-6, Clone 15: Tg 3.1-2, Clone 17: Tg 59.2-7, Clone 26: Tg 70.2.3-7, Clone 13: FK Sh 1.1.3-10, and Clone 18: Tg 59.2-8 indicated superiority and potential to be improved as high yield clones of abaca.

\section{REFERENCES}

1. Batalon, L.J.S., Abustan, M.A.M, Lalusin, A.G. 2014. Development of abaca (Musa textilis Nee) cultivars with resistance to major abaca viruses through mutation breeding. http://agris.fao.org/agrissearch/search.do;isessionid $=02$ bab636d5b0384edb0319b3d61ddc78?request [accessed July 12, 2018].

2. Berenschot, A.S., Zucchi, M.I., Tulmann-Neto, A. and Quecini, V. 2008. Mutagenesis in Petunia $\mathrm{x}$ hybrida Vilm. and isolation of a novel morphological mutant. Braz. J. Plant Physiol., 20(2):95-103

3. Dizon, T.O., Damasco, O.P., Lobina, I.T., Pinili, M.S., Lalusin, A.G., Natsuaki, K.T. 2012. Induction of putative resistant lines of abaca (Musa textilis Nee) to banana Bunchy Top Virus and Banana Bract Mosaic Virus through in vitromutagenesis. J. ISSAAS 18 (1): 8799

4. Dwiatmini, K., Kartikaningrum, S., and Sulyo, Y. 2009, Induksi Mutasi Kecombrang (Etlingera elatior) Menggunakan Iradiasi Sinar Gamma, J. Hort. 19 (1): 1-5.

5. Gichner, T. 2003. Differential genotoxicity of ethyl methanesulphonate, N-ethyl-Nnitrosourea and maleic hydrazide in tobacco seedlings based on data of the Comet assay and two recombination assay. Mutation Res. 538:171-179.

6. Heliyanto, B., Setyo-Budi, U. and Sudarmo, H. 1999. Selection criterion for rami (Boehmeria nivea Gaud). http://agris.fao.org/agrissearch/search/display/do? $\mathrm{f}=2000 \% 2 F I D \% 2 I F D 00014 . x m l \% 3 B I D 2000000419$ [accessed April 28, 2015].

7. Krishna, H., Alizadeh, M., Singh, D., Singh, U., Chauhan, N., Eftekhari, M., Sadh, R. K. 2016. Somaclonal variations and their applications in horticultural crops improvement. https://www.researchgate.net/publication/294421158_Somaclonal_variations_and_their_ applications_in_horticultural_crops_improvement [accessed July 12,2018$]$.

8. La-Vina, H.C.1993. Stability of yield and fiber fineness in rami (Boehmeria nivea Gaud). http://agris.fao.org/agrissearch/search/display/do?

$\mathrm{f}=1994 \% 2 \mathrm{FPH} \% 2 \mathrm{FPH} 94008 . x \mathrm{ml} \% 3 \mathrm{BPH} 9410635$ [accessed April 28, 2015]. 
9. Moedjiono dan Mejaya, M.J., 1994, Variabilitas genetik beberapa karakter plasma nutfah jagung koleksi Balittan Malang. Zuriat: 5 (2): pp. 27-32.

10. Purwati, R.D., Sudjindro, Kartini, E, dan Sudarsono, 2008, Keragaman genetika varian abaca yang diinduksi dengan Ethylmethane Sulphonate (EMS). Jurnal Littri 14 (1), Maret 2008. pp. 16-24.

11. Roychowdhury, R. and Tah, J. 2011. Assessment of chemical mutagenic effects in mutation breeding programme for M1 generation of Carnation (Dianthus caryophyllus). Research in Plant Biology, 1(4):23-32.

12. Russell, P.J. 1992. Genetics (Third edition). Harper Collins Pub. New York.758p.

13. Santoso, B., Mastur, Kadarwati, F.T. 2016. Abaca (Musa textilis, Nee) as the source of natural fiber, producing raw material for pulp and source of farmer income. Perspektif 15 (1): 01-10.

14. Setyo-Budi, U., Sudjindro, Purwati, R.D. 2001. Status plasma nutfah abaca menyongsong program agribisnis abaca di Indonesia. Prosiding Simposium Pemuliaan VI. Kontribusi Pemuliaan dalam Inovasi Teknologi Ramah Lingkungan dalam Kasno, A. et al. (eds). PERIPI Komda Jatim. P. 254-258.

15. Upov, 2008. Banana MUSAA_ACU; MUSAA_PAR Musa acuminate Colla; Musa $x$ paradisiaca L. Guidelines for the Conduct of Tests for Distinctness, Uniformity and Stability. International Union for The Protection of New Varieties of Plants. Geneva

16. Wang, L., Zhang, B., Li, J., Yang, X., Ren, Z. 2014. Ethyl Methanesulfonate (EMS)Mediated Mutagenesis of Cucumber (Cucumis sativus L.). Agricultural Sciences 5:716721.

17. Wattoo, J. I., Aslam, K., Shah, S. M., Shabir, G., Sabar, M., Naveed, S. A., Waheed R., Samiullah, Muqaddasi, Q. H. and Arif, M. 2013. Ethyle methane sulphonate (EMS) induced mutagenic attempts to create genetic variability in Basmati rice. African Journal of Water Conservation and Sustainability Vol. 1 (3):045-048.

18. Yadav, P., Meena, H.S., Meena, P.D., Kumar A., Gupta, R., Jambhulkar, S., Rani, R., Singh, D. 2016. Determination of LD50 of ethyl methanesulfonate (EMS) for induction of mutations in rapeseed-mustard. Journal of Oilseed Brassica 7(1):77-82.

19. Zapico, F.C.L., Aguilar, C.H.M., Aujero, J.M., Disca, B.Y. 2010. Paternity testing of selected abaca (Musa textilis Nee) hybrids using morphometric markers. J.of Agric. Sci and Tech. 4 (5):101-105.

20. Zia, M.A.B., Bakhsh, A., Caliskan, M.E. 2018. Mutation breeding in potato; endeavors and challenges. The Journal of Animal \& Plant Sciences 28 (1):177-186. 